\title{
Functional Foods, Old Age and Diabetes
}

\author{
Marta Coronado Herrera', Rey Gutiérrez Tolentino ${ }^{1}$, Salvador Vega y León ${ }^{1}$, \\ Claudia Radilla Vázquez², Marcela Vazquez Francisca3 ${ }^{3}$, María de Lourdes Ramírez Vega² \\ ${ }^{1}$ Department of Agricultural and Animal Production, Universidad Autónoma Metropolitana-Xochimilco, \\ Distrito Federal, México \\ ${ }^{2}$ Department of Health Care, Universidad Autónoma Metropolitana-Xochimilco, Distrito Federal, México \\ ${ }^{3}$ Master of Agricultural Sciences, Universidad Autónoma Metropolitana-Xochimilco, Distrito Federal, México \\ Email: reygut@correo.xoc.uam.mx
}

Received 16 October 2015; accepted 11 December 2015; published 14 December 2015

Copyright (C) 2015 by authors and Scientific Research Publishing Inc.

This work is licensed under the Creative Commons Attribution International License (CC BY).

http://creativecommons.org/licenses/by/4.0/

c) (i) Open Access

\begin{abstract}
The aim of this paper is to analyze aspects of nutrition and nourishment among elderly diabetic people. It is presented the current research of products with functional food properties that provide not only nutritional value but also other components which encourage a better quality of life during aging. In addition, it includes natural and industrialized functional foods that are commercialized and may be good for daily consumption.
\end{abstract}

\section{Keywords}

Old Age, Functional Foods, Type 2 Diabetes

\section{Introduction}

The objective of the present study is to emphasize the importance of healthy eating for the elderly, especially those with type 2 diabetes. This pathology is frequent during the human aging process, and in fact, it is considered that $15 \%$ of the population presents this disease after the age of 70 years.

In this context, a healthy proposal may include the consumption of functional foods, of which various suggestions are included in this text.

\section{Human Aging}

According to the World Health Organization (WHO), an elderly adult is 64 years or more [1], and although it cannot be specified exactly when aging begins, some authors point out that maximum human vitality occurs at 30 years of age, from which point the changes that lead to old age progressively take place [2].

Among the alterations associated with eating and nutrition are the loss of lean mass and reduction of height.

How to cite this paper: Coronado, H.M., Gutiérrez, T.R., Vega, L.S., Radilla, V.C., Vazquez, F.M. and Ramírez, V.M.L. (2015) Functional Foods, Old Age and Diabetes. Food and Nutrition Sciences, 6, 1507-1513. 
In the gastrointestinal system, there is a reduction in the secretion of hydrochloric acid, leading to the lack of absorption of iron and other minerals and low production of the intrinsic factor. This lack of hydrochloric acid propitiates the pepsinogen from transforming to pepsin, with the consequent alteration of the digestion of proteins or an efficient elimination of bacteria, thus leading to poor digestion [2].

The absorptive area of the intestine is diminished, thus reducing lactase. Similarly, there is an increased risk of osteoporosis, due to an affectation of the metabolism of calcium and vitamin $\mathrm{D}$, which also has a reduced cutaneous biosynthesis.

Another common problem is constipation, with slow intestinal transit and the dietary lack of fiber and liquids. Added to the above, the older adult is inclined to the overuse of pharmaceuticals, which inhibits the absorption of nutrients [3] and causes medicinally induced gastritis [4].

The following section will include an analysis of the health alterations associated with type 2 diabetes.

\section{Diabetes and Its Relationship with Old Age}

Type 2 diabetes is a disease present in the population affecting approximately 220 million adults, calculated in a projection for the year 2010 [5].

Furthermore, if it is associated with old age, one out of every ten inhabitants in the world is presently (2013) over the age of 60, with a million more every month. Thus, in the next 17 years, a billion two hundred thousand of this group will be susceptible to developing type 2 diabetes, which may increase even more if the present life expectancy is considered along with greater efficiency in the detection of the disease [6]. This presents a health problem to be confronted and studied now.

The term diabetes has ancient origins, when the Roman physician Arateus gave it the name from the relationship with its symptomatology, polyuria (water that passes through a siphon). It was later identified as "honey urine” by Hindu medicine, and more recently (XVIII century) the Scotsman William Cutler referred to it as diabetes "mellitus" due to its association with honey [7]. As an important historical fact, it is also important to mention the discovery of insulin (1921), by a medical team directed by the Canadian Frederick Banting, who used it in the treatment of diabetes.

According to the literature, in general this disease appears in the older adult after the age of 65, and some individuals who presented it earlier may have the symptoms of the onset of the disease, or be unaware of its presence [5].

This pathology is also defined as a multi-causal metabolic disorder, whose best known symptom is a high concentration of glucose in blood above the recommended normal level $(100 \mathrm{mg} / \mathrm{dL})$.

The phenomenon can be associated with a reduction in the production of insulin or a deficiency in its utilization (insulin resistance). An important fact is that in thin individuals there is a lower insulin requirement, while obese patients require higher doses to maintain a normal glycemia [5].

One of the causes of diabetes in older adults is due to the peripheral resistance to the utilization of glucose, perhaps because of the modification in the receptors and a lower efficiency of insulin [1].

In old age diabetes, the blood concentration of glucose can lead to an autoxidation or the production of glycosylation of proteins (of serum), forming the Amadori compounds or free radicals from oxygen, which are highly reactive elements [8] and representing a problem for the organism.

In synthesis, among the risk aspects for developing diabetes in old age, the following should be mentioned: lowered physical activity, lower production of insulin and insulin resistance, along with the consumption of diuretics, steroids, phenytoin, niacin, ephedrine (polypharmacy), among other medications that are hyperglucemiants, associated with other diseases that appear in old age [9].

Several complications may occur in an older adult with diabetes. These may include nephropathy and diabetic neuropathy. Dental alterations may also occur, with the presence of cavities and periodontal problems that imply the involution of pulp, bones, maxillaries, oral mucosa and salivary glands, leading to the deterioration of eating and nutrition. Visual problems are also frequent with the consequent presence of cataracts, glaucoma or diabetic retinopathy.

Other problematics are associated with the cardiovascular system, with the presence of hypertension, or a deficient blood circulation that can lead to lack of nerve sensitivity and the risk of diabetic foot, frequent in the older adult with diabetes [5].

It would be lengthy to go into depth in all of the ailments derived from the presence of type 2 diabetes in old 
age. Therefore, according to the objective of the present text, the variable of highest relevance to analyze is the food proposal with special emphasis on functional foods.

\section{Functional Foods}

In principal, there are several definitions of functional foods. However, the following may express the basic ideas. It considers foods with a healthy message, and that added to their basic nutrimental value, contain other nutrients, substances or nutritional composition that prevent or reduce the risk of a diet that leads to the disease, or increases certain important physiological functions [10].

The functional foods also consider natural or processed products of plant or animal origin. In the case of processed foods, they can be made with the elimination of an unhealthy component, such as the reduction of sodium, sugar or saturated fatty acids. Chemical modifications are also considered, such as hydrolyzed proteins for allergy problems. Others may include the addition of some nutrient such as eggs with omega-3 [11].

They may also contain natural bioactive substances such as the plant sterols (corn, sunflower, soybean or coconut palm oil) or the lycopene of tomato. They are in fact foods of everyday consumption in the diet that comply with a function during plant or animal life, and then enrich the human diet [12] [13].

In this context some functional foods are also known as designed products, such as low-fat yoghurt with granola to reduce blood glucose or bread enriched with omega-3 which can reduce cholesterol due to its high content of soluble fiber. Also products with pre-biotics aid in the gastrointestinal equilibrium [10].

Another group of functional foods to consider includes those without (with low fat, low in cholesterol and calories) or those offered with, referring to the addition of vitamins or omega-3 and/or 6 fatty acids. In the case of the non-fat or light foods, they imply the reduction of components associated with some chronic diseases such as diabetes or cardiovascular ailments. Thus there are foods that are low sodium, without cholesterol and sugarless (with sweeteners such as aspartame, acesulfame K or sucralose) or the fat free foods [13].

\section{Proposal of Functional Foods for the Elderly}

In recent years a number of research centers have focused on the search for foods for the elderly, particularly mixtures which supply the required nutrients and aid in food consumption and nutrition of those who have an associated ailment, such as type 2 diabetes.

In principle, it is important to revise the nutritional requirements for the elderly and to consider that these decrease with age, as there is a reduction in muscular mass and physical activity. With respect to calories, about 2150 are recommended for men and 1680 for women. Of complex carbohydrates (with fiber) from $50 \%-60 \%$ of the total calories are recommended, $15 \%(<1 \mathrm{~g} / \mathrm{Kg}$ of weight/day of proteins) and $20 \%-30 \%$ of lipids of the total calories/day. Of these $<200 \mathrm{mg} / \mathrm{d}$ of cholesterol, $7 \%-10 \%$ of saturated fatty acids and $<10 \%$ of polyunsaturated fatty acids of the total calories are considered recommendable [2] [14] [15].

With respect to proteins, the supply should be no less than $12 \%$ of the caloric total, because if energy consumption is reduced, aging affects the utilization of this nutrient, and a negative nitrogen balance can be observed in the elderly, added to pathologies from chronic illnesses [16].

In continuation various proposals of functional foods will be analyzed, especially the food mixtures and fresh and industrialized products (Table 1 and Table 2) that can be included in the daily diet of the elderly with type 2 diabetes.

Among the present proposals of mixtures for the elderly some rich in proteins and reduced in fat and sugar have been analyzed [2].

For this purpose, patés, purees and creams have been prepared. With respect to patés, a formula has been prepared with chicken liver and inuline, one with liver, one with chicken meat and inuline, another with beef liver and finally one with chicken liver and chicken meat. All of these mixtures were prepared for elderly persons with diabetes. These products satisfy (100 g of product) a major part of the nutrimental requirements for the age and gender.

The sensorial evaluation was made with 80 trained elderly judges, and a high acceptance (87\%) of the products was observed. Other foods prepared by the same research group [2] were cream of carrot, beet, spinach with soy milk and inuline and carrot with soy and inuline, along with lentil pure and of squash with spinach. All of these products had equal acceptance (approximately 87\%) of the elderly panelists.

At this point we will mention the study of Lutz et al. [3], that analyzes the elaboration of foods for the elderly that not only were culinary preparations of the region, but that supplied bioactive elements found in functional foods, such as omega-3 fatty acids, phytoestrogens and antioxidants. It is suggested that these foods can benefit health and reduce the risk of chronic diseases or aid in their treatment in the elderly. 
Table 1. Recommended natural functional foods.

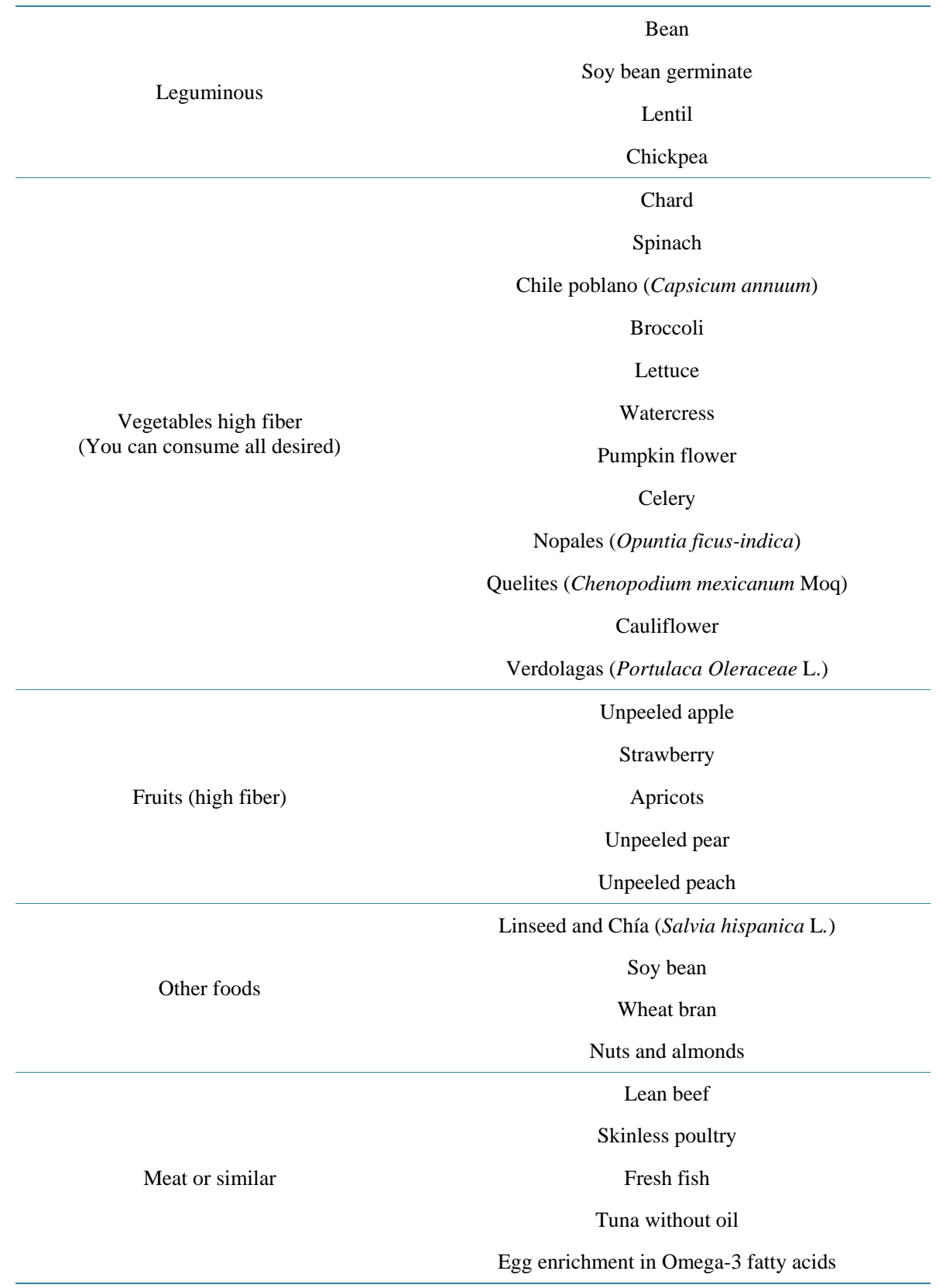

Source: Prepared by the authors using data from the cited articles.

In the abovementioned study, the source of the phytoestrogens consisted of foods with isoflavones, genistein and daidzein and some with phytochemicals to supply other antioxidants.

A type of low sodium, low fat spreadable paste has also been proposed, prepared from turkey, pre-biotics, vitamins, minerals and antioxidants. This functional paste was tasted on crackers and was evaluated by trained subjects from 60 to 85 years of age, with good result (90\%) of acceptability [17].

Another dish prepared for elderly subjects is a cream soup with squash flour (Curcubita maxima), tree bean (Cajanus indicus) and spices (garlic powder, coriander and onion).

Thus, at present foods are sought that satisfy the nutrimental requirements during old age and which aid in the treatment of associated pathologies.

Another investigation considers formulations that are easily consumed and masticated, and that have good 
Table 2. Commercially processed functional foods.

\begin{tabular}{l}
\hline Cracker (low fat, low sodium) \\
Cookies light (low fat, sugarless) \\
Toast with double fiber \\
Wholemeal bread \\
Rye bread \\
Integral rice \\
Corn tortilla \\
Jam sugarless \\
Sugar-free gelatin \\
Panela cheese light \\
Light lactose-free Manchego cheese \\
Light milk lactose-free with added calcium, vitamins A and D \\
Light natural yogurt (sugarless, lactose free) \\
Light mayonnaise \\
Ham turkey (breast)
\end{tabular}

Source: Prepared by the authors using data from local market.

sensorial characteristics. Among the proposals are the purees or instant soups made from cereals and legumes, with added calcium. Spaghettis and cookies enriched with fiber (bran flour) and gluten are also proposed, to reduce the problem of intestinal transit and above all which aid in the feeding of older adults with type 2 diabetes [18].

In these light or sugarless products, it is important to observe the labels for the type of sweetener they contain (aspartame, acesulfame-k, stevia or others). The older adult with diabetes should avoid sorbitol, as it provokes diarrhea. The over-consumption of artificial sweeteners should also be avoided [5].

It should also be remembered that although some commercially offered processed foods indicate that they are safe for diabetic individuals, their consumption should be watched, because there is a tendency to use large quantities of these products, with the risk of increasing glycemia.

It is recommendable to watch the consumption of fruit. Although fruit is beneficial for the elderly diabetic individual, some have a high sugar content that is rapidly absorbed. Such is the case of fruit juices (orange, tangerine, grapefruit), banana, grapes, pineapple, watermelon, figs, cherries, mango, among others.

Some additional recommendations for the diet of elderly subjects with diabetes is to avoid the consumption of pre-cooked products or pre-frozen preparations. Fried products should also be avoided, along with animal fat, mayonnaise and margarine. Instead, vegetable oils (olive) may be consumed. It is also recommended to reduce the consumption of salt, condiments, hot spices and coffee. Every meal should include small rations, because large volumes produce difficult digestion with postprandial abdominal distention. Meals should be consumed at regular hours, five times a day (2 snacks), which aids in the control of glycemia and to prevent fluctuations in its levels.

The consumption of liquids is important (approximately 2 liters per day) such as water, sugarless juices or soups. Sugar should not be present in foods (desserts, breads, cookies, soft drinks, juices or others). It is important to increase the consumption of fruits and vegetables, especially those low in carbohydrates and to include dry fruits.

It is also important to remember that a person's diet is a cultural phenomenon associated to symbolisms (reunions, family gatherings, celebrations, etc.), thus the food that is offered to the elderly diabetic subject should consider the affective motivations (the urge for certain foods, taste, and the pleasure of eating). Changes should be observed slowly and by stages with a guide that helps to reflect as Bravo [4] indicates, that eating well is living well. Also, consider the somewhat philosophical reflection of the millenary past (especially in the orient) with respect to the consumption of some foods that could be used as medicine (saffron, ginger, mint or others) 
and the popular notion of "food as medicine”, paradigm which is applicable to functional foods [19].

\section{Conclusions}

Diet for the elderly requires particular care, because of the changes generated by the aging process, such as those mentioned in the present article. This is even more important if the older adult has type 2 diabetes, which is frequent in this stage of life (approximately 15\%).

On the other hand, although the diet of the elderly may be the same as that of a normal individual, the presence of an illness such as diabetes requires a different nutritional care, which can even aid in the integral control of the disease.

Furthermore, the cost of health care of the older adult is increasingly higher for government institutions, thus the availability of functional foods which supply health benefits is an attractive proposal for prevention in the care of the consumer.

Therefore, this article offers a food proposal, both of fresh and industrialized functional foods, whose present supply in the market is ample and with costs accessible to the population.

However, diabetics elderly people should consult with their doctor not only about medications but also about functional foods proposed in this paper.

\section{References}

[1] Restrepo, S., Morales, R., Ramírez, M., López, M. and Varela, L. (2006) Los hábitos alimentarios en el adulto mayor y su relación con los procesos protectores y deteriorantes en salud. Revista Chilena de Nutrición, 33, 13. http://dx.doi.org/10.4067/s0717-75182006000500006

[2] Espinosa, C. (2011) Diseño de alimentos para personas diabéticas de la tercera edad. Maestría en Ciencias de los Alimentos, Instituto Politécnico Nacional.

[3] Lutz, M., Morales, D., Sepúlveda, S., and Alviña, M. (2009) Evaluación sensorial de preparaciones elaboradas con nuevos alimentos funcionales destinados al adulto mayor. Revista Chilena de Nutrición, 35, 131-137.

[4] Bravo, S. (2003) Alimentación durante la vejez. En: AMMFEN (Asociación Mexicana de Facultades y Escuelas de Nutrición), XVIII Congreso Nacional de AMMFEN. Querétaro, México, Edición Especial No. 5-2003.

[5] Pérez, M. and Ruano, A. (2004) La alimentación de los ancianos diabéticos. Consejos dietéticos desde la farmacia. Revista de la Oficina de Farmacia (OFFARM), 23, 80-86.

[6] Acevedo, A., Pulido, J., Armas, M. and Rech, A. (2013) El ejercicio físico en pacientes de la tercera edad con diabetes mellitus tipo 2. Nguyen Van Troi, 2010. Revista Cubana de Tecnología de la Salud, 4, 10.

[7] Instituto Nacional de Estadística y Geografía (INEGI) (2013) Estadística a propósito del día mundial de la diabetes. INEGI, Aguascalientes.

[8] Zorrilla, A. (2002) El envejecimiento y el estrés oxidativo. Revista Cubana de Investigaciones Biomédicas, 21, 178-185.

[9] Velasco, D., Álvarez, O., Padilla, C. and Ochoa, T. (2013) Comportamiento de algunos factores de riesgo de aterosclerosis y enfermedades consecuentes en pacientes diabéticos de la tercera edad. Revista Finlay, 3, 165-171.

[10] Landström, E., Hursti, U. and Magnusson, M. (2009) Functional Foods Compensate for an Unhealthy Lifestyle. Some Swedish Consumers Impressions and Perceived Need of Functional Foods. Appetite, 53, 34-43. http://dx.doi.org/10.1016/j.appet.2009.04.219

[11] Millone, M., Olagnero, G. and Santana, E. (2011) Alimentos funcionales: Análisis de la recomendación en la práctica diaria. Diaeta (B. Aires), 29, 7-15.

[12] Jones, P. (2002) Functional Foods More than Just Nutrition. Canadian Medical Association Journal, 166, $1555-1563$.

[13] Vega, S. (2003) Innovaciones alimentarias al inicio del siglo XXI. En: Coronado, M. (comp.), La innovación tecnológica en el futuro de los profesionales en áreas biológicas. Un texto para estudiantes universitarios. México, D.F.: UAM-X, UAEM, 285 p.

[14] FAO/WHO/UNU (1985) Energy and Protein Requirements. World Health Organization, Geneva.

[15] Secretaría de Salud, S.S. (2008) Protocolo para orientación nutricional en la prevención y control de enfermedades crónicas: Sobrepeso, Riesgo Cardiovascular y Diabetes.

http://www1.paho.org/prfep/capacitacion/5\%20Secretaria\%20de\%20Salud\%20de\%20Mexico/version\%20final\%20mat eriales\%202008/Preprensa\%20Manual\%20de\%20informacion\%20COA/Manua\%20Informacion.pdf 
[16] Cervantes, L., Montoya, M., Núñez, L., Borges, A., Gutiérrez, L. and Llaca, C. (2003) Aporte dietético de energía y nutrimentos en adultos mayores en México. Nutrición Clínica, 6, 2-8.

[17] Garrido, F., González, S., Dondero, M. and Wittig de Penna, E. (2010) Pasta untable de pavo enriquecida con fibras, vitaminas y minerales antioxidantes como ingredientes funcionales para el adulto mayor. Revista Chilena de Nutrición, 37, 360-368. http://dx.doi.org/10.4067/s0717-75182010000300011

[18] Praderes, G., García, A. and Pacheco, E. (2010) Elaboración de una sopa instantánea dirigida al adulto mayor, con inclusión de harinas gelatinizadas del fruto de auyama (Cucurbita máxima L.) y granos de quinchoncho (Caja L.). Revista de la Facultad de Agronomía, 36, 107-115.

[19] Cortés, M., Chiralt, A. and Puente, L. (2005) Alimentos funcionales: Una historia con mucho presente y futuro. Vitae, 12, 5-14. 